\title{
Modelling of Experimental Tests of Wooden Specimens from Scots Pine (Pinus sylvestris) with the Help of Anisotropic Plasticity Material Model
}

\section{Modeliranje eksperimentalnih ispitivanja uzoraka izrađenih od drva običnog bora (Pinus sylvestris) uz pomoć modela za anizotropno-plastične materijale}

\author{
Original scientific paper • Izvorni znanstveni rad \\ Received-prispjelo: 9. 12. 2013. \\ Accepted-prihvaćeno: 14. 1. 2015. \\ UDK: $630 * 812.702 ; 674.032 .475 .442$ \\ doi:10.5552/drind.2015.1362
}

\begin{abstract}
In order to describe the behaviour of wood when calculating wooden elements and structures with the use of the finite element method, orthotropic material model in combination with non-interactive (maximum stress criterion) or interactive failure criteria (Hoffman and Tsai-Wu criterion) is used. Another option is to use a general anisotropic plasticity material model complemented with a non-interactive failure criterion - maximum stress criterion, which allows to describe wood failure by brittle failure in tension. The presented general material model was used in combination with the idealization of annual rings by cylindrical surface for the modelling of wood specimen tests form Scots pine (Pinus sylvestris). The obtained results show good agreement between the results of numerical analysis and experimental testing of wood specimens. The use of the anisotropic material model can also be seen in cases when the level of the applied load is higher than the level when the failure of wooden material occurs.
\end{abstract}

Key words: Scots pine (Pinus sylvestris), FEA, numerical modelling, elastic constants, material constants, anisotropic plasticity

SAŽETAK・ Radi objašnjenja ponašanja drva pri proračunima drvnih elemenata i konstrukcija primjenom metode konačnih elemenata, upotrijebljen je model ortotropnog materijala u kombinaciji s neinteraktivnim kriterijem (kriterij maksimalnog naprezanja) ili interaktivnim kriterijima loma (Hoffmanov i Tsai-wuov kriterij). Druga je mogućnost upotrijebiti opći model za anizotropno-plastične materijale dopunjen neinteraktivnim kriterijem loma - kriterijem maksimalnog naprezanja, koji omogućuje objašnjenje lomljivosti drva pri naprezanju. Predstavljeni opći model materijala u kombinaciji s idealizacijom godova kao cilindričnih površina upotrijebljen je za modeli-

\footnotetext{
${ }^{1}$ Author is assistant professor at Brno University of Technology, Faculty of Civil Engineering, Institute of Building Structures, Brno, Czech Republic.

Autor je docent Tehnološkog sveučilišta u Brnu, Građevinski fakultet, Zavod za građevinske konstrukcije, Brno, Republika Češka.
} 
ranje uzoraka izrađenih od drva običnog bora (Pinus sylvestris). Dobiveni rezultati pokazuju dobru podudarnost rezultata numeričke analize i rezultata eksperimentalnih ispitivanja uzoraka drva. Model anizotropnog materijala primjenjiv je i kada je opterećenje veće od onoga pri kojemu dolazi do loma drvnog materijala.

Ključne riječi: obični bor (Pinus sylvestris), FEA, numeričko modeliranje, elastične konstante, materijalne konstante, anizotropna plastičnost

\section{INTRODUCTION 1. UVOD}

Despite the high abundance of Scots pine (Pinus sylvestris) in mild and colder Eurasia climate (Úřadníček et al., 2001; 2012a), few literature sources contain information on elastic and material constants of this tree species, which could be used for an analysis with the use of anisotropic plasticity material model. Anisotropic plasticity material model defined by 9 elastic and 18 material constants is described by Moses and Prion (2004) as a general material model, which allows to define different bilinear elasto-plastic behaviour with possible hardening of material in three perpendicular directions, including the definition of different behaviour in these directions in tension, compression, and shear.

Elastic and material constants are predominantly specified for Loblolly pine (Pinus taeda) (Bergman et al., 2010; Bodig and Goodman, 1973; Morais et al., 2001; Jeong et al., 2010) and for Douglas fir (Douglas fir) (Bergman et al., 2010; Bodig and Goodman, 1973; Winandy, 1994; Nairin, 2007; Kim and Harries, 2010).

Elastic constants for Scots pine (Pinus sylvestris), shown by Bodig and Goodman (1973) and Martin and Berger (2001), are based on a special report produced by R. F. S. Hearmon (Hearmon, 1948). Elastic constants for Scots pine used for the modelling of a section of a wooden string staircase and stair joints are also presented by Pousette (2006). Elastic and material constants of Scots pine are shown by Danielsson and Gustafsson (2013), who used these constants for the modelling of a double cantilever beam (DCB) and endnotched beams. According to Danielsson and Gustafsson (2013), the specified constants are in compliance with the values for Norway spruce (Picea abies). The values of elastic and material constants of Scots pine are shown in the papers of Matovič (1993) and Požgaj et al. (1997; 2004).
For the purpose of the numerical analysis of a prefabricated suspended staircase from Scots pine (Pěnčík, 2013), elastic and material constants of the Scots pine were selected with the use of results presented in the papers of Matovič (1993) and Požgaj et al. (1997; 2004). The constants are shown in Table 1, where $E$ is modulus of elasticity in material directions (longitudinal $L-E_{\mathrm{L}}$, radial $R-E_{\mathrm{R}}$ and tangential $T-$ $\left.E_{\mathrm{T}}\right), G$ is shear modulus in material planes $\left(G_{\mathrm{RT}}, G_{\mathrm{LT}}\right.$, $\left.G_{\mathrm{LR}}\right), v$ Poisson's ratio $\left(v_{\mathrm{RT}}, v_{\mathrm{LT}}, v_{\mathrm{LR}}\right), f_{\mathrm{Lt}}, f_{\mathrm{Rt}}, f_{\mathrm{Tt}}$ are strengths in tension and $f_{\mathrm{Lc}}, f_{\mathrm{Rc}}, f_{\mathrm{Tc}}$ are strengths in compression in material directions $L, R$ and $T, f_{\mathrm{LR}}, f_{\mathrm{LT}}, f_{\mathrm{RT}}$ are shear strengths in material planes.

The elastic constants (Table 1) were selected taking into account the meeting of criteria presented in relation (1) (Gillis, 1972; Hallai, 2008) and in relation (2) (Xavier, 2007), which express their inter-relation.

$$
\begin{gathered}
E_{L}>E_{R}>G_{L R} \approx G_{L T}>E_{T}>G_{R T} \\
E_{L} \gg E_{R}>E_{T}, G_{L R}>G_{L T} \gg G_{R T}, v_{L R}>v_{L T}>v_{R T}
\end{gathered}
$$

The verification of elastic and material constants (Table 1) was performed by a numerical modelling of experimental testing with the use of finite element calculation using software ANSYS (ANSYS, 2012a).

\section{MATERIAL AND METHODS} 2. MATERIJAL I METODE

\subsection{Experimental testing}

\subsection{Eksperimentalno ispitivanje}

Wooden specimens made of Scots pine (Pinus sylvestris) were prepared in compliance with ČSN EN 408. The dimensions of the cross section - width $(b)$ and height $(h)$ and length $(L)$ of specimens were selected in compliance with the requirements of ČSN EN $408 ; b \times h \times L=25 \times 25 \times 475 \mathrm{~mm}$. Before the testing, the specimens were conditioned in a standard environment at the temperature of $20 \pm 2{ }^{\circ} \mathrm{C}$ and relative

Table 1 Elastic and material constants of Scots pine (Pinus sylvestris) in MPa

\begin{tabular}{|c|c|c|c|c|c|c|c|c|}
\hline \multicolumn{9}{|c|}{$\begin{array}{l}\text { Elastic constant for orthotropic and anisotropic plasticity material model } \\
\text { Elastične konstante za model ortotropnoga i anizotropnoga plastičnog materijala }\end{array}$} \\
\hline$E_{\mathrm{L}}$ & $E_{\mathrm{R}}$ & $E_{\mathrm{T}}$ & $G_{\mathrm{RT}}$ & $G_{\mathrm{LT}}$ & $G_{\mathrm{LR}}$ & $v_{\text {RT }}$ & $v_{\mathrm{LT}}$ & $v_{\mathrm{LR}}$ \\
\hline 14300 & 700 & 545 & 500 & 800 & 1230 & 0.380 & 0.040 & 0.030 \\
\hline \multicolumn{9}{|c|}{ Material constant / Materijalne konstante } \\
\hline$f_{\mathrm{Lt}}$ & $f_{\mathrm{Lc}}$ & $f_{\mathrm{Tt}}$ & $f_{\mathrm{Tc}}$ & $f_{\mathrm{Rt}}$ & $f_{\mathrm{Rc}}$ & $f_{\text {LR }}$ & $f_{\mathrm{LT}}$ & $f_{\mathrm{RT}}$ \\
\hline 103.0 & 48.5 & 3.5 & 7.6 & 5.4 & 5.2 & 7.5 & 7.3 & 2.3 \\
\hline$R_{\mathrm{b}}$ & $E_{\mathrm{b}}$ & $\rho$ & & & & & & \\
\hline 86 & 12800 & 505 & & & & & & \\
\hline \multicolumn{9}{|c|}{$\begin{array}{l}\text { Adjusted material constant for anisotropic plasticity material model } \\
\text { Prilagodba materijalnih konstanti za model anizotropnoga plastičnog materijala }\end{array}$} \\
\hline$f_{\mathrm{Lt}}$ & $f_{\mathrm{Lc}}$ & $f_{\mathrm{Tt}}$ & $f_{\mathrm{Tc}}$ & $f_{\mathrm{Rt}}$ & $f_{\mathrm{Rc}}$ & $f_{\mathrm{LR}}$ & $f_{\mathrm{LT}}$ & $f_{\mathrm{RT}}$ \\
\hline 101.0 & 43.0 & 4.927 & 5.4 & 5.4 & 5.2 & 7.5 & 7.3 & 2.3 \\
\hline
\end{tabular}

Tablica 1. Elastične konstante i materijalne konstante drva običnog bora (izražene u MPa) 
(a)

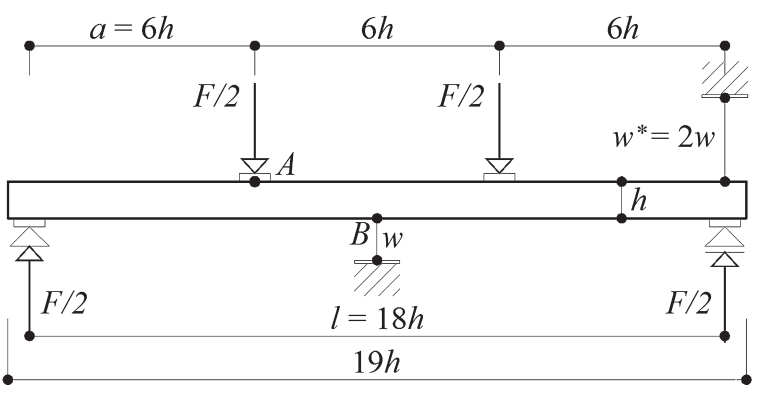

(b)

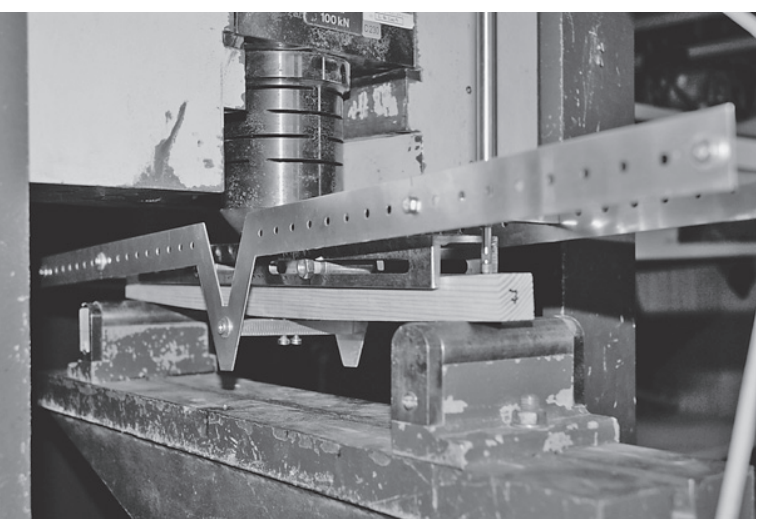

Figure 1 Arrangement of the test in compliance with ČSN EN 408 (a) and specimen No. 7 with a steel V-shape fixture (b) Slika 1. Skica ispitivanja u skladu s normom ČSN EN 408 (a) i uzorak broj 7 čeličnim učvršćenjem V-oblika (b)

humidity of $65 \pm 2 \%$ until reaching constant weight (Kuklík and Vídeňský, 2005). In total, 10 specimens were prepared.

The specimens were simply supported during the experimental testing. The specimens were loaded by four-point bending (Fig. 1). The distance between supports was $450 \mathrm{~mm}(18 \cdot h)$. The testing set was complemented with a developed steel V-shape fixture (Fig. 1), which prevented transversal displacement of the tested specimens, while allowing their bending.

For the purpose of the monitoring of vertical displacement $w^{*}$ (Fig. 1), testing specimens were fitted on the right support at their upper surface, with an inductive standard displacement transducer HBM WA-T/50 mm (HBM, 2012), with the measuring range of $0-50 \mathrm{~mm}$ and accuracy of $0.001 \mathrm{~mm}$. The vertical displacement $w$ at midspan was converted with the use of the measured vertical displacement $w^{*}\left(w=w^{*} / 2\right)$. The load was derived from the mechanical testing press FPZ100. The magnitude of the loading force was recorded by a calibrated resistance load cell. All sensors were connected to an 8-channel measuring data logger HBM Spider 8 (HBM, 2006). The data were recorded with the recording frequency of $2 \mathrm{~Hz}$, i.e. in the time interval of $0.2 \mathrm{~s}$.

\subsection{Results of experimental testing}

2.2. Rezultati eksperimentalnog ispitivanja

The relation of applied load $F$ on vertical load $w$ (load-displacement diagram $F-w$ ) for the whole inter-

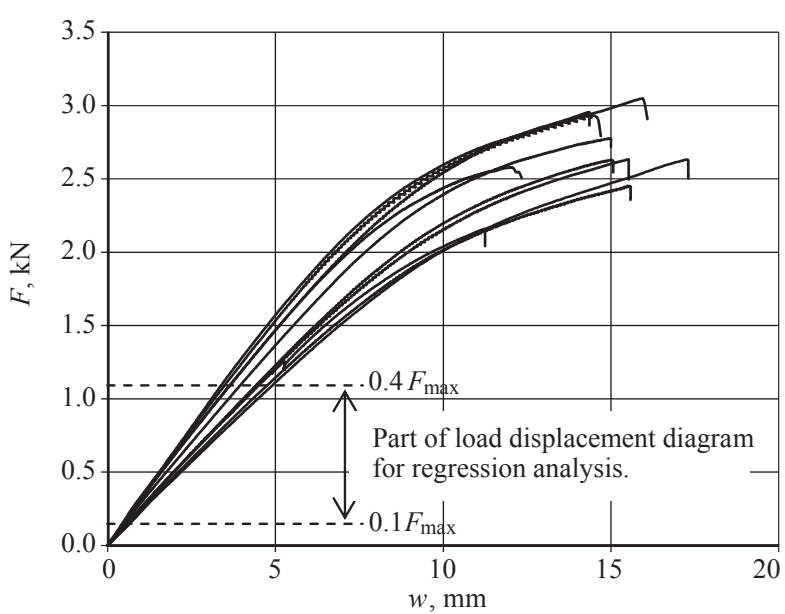

Figure 2 Load displacement diagram $(F-w)$ for the whole loading interval

Slika 2. Dijagram opterećenje - pomak $(F-w)$ za cijeli interval opterećenja

val of loading and all specimens is shown in Fig. 2. The load displacement diagram for individual specimens is shown in Fig. 5. The average value of limit load $F_{\text {max }}$ is $2.693 \mathrm{kN}$ (Table 2). The regression analysis and the determination of modulus of elasticity in bending used the part of graph in the interval $0.1 \cdot F_{\text {max }}$ to $0.4 \cdot F_{\text {max }}$, i.e. the part with linear relationship between load $F$ and displacement $w$ (Fig. 2) with the value of reliability $R^{2}$ higher than 0.99 (Kuklík and Vídeňský, 2005).

Table 2 Experimentally measured values for individual specimens

Tablica 2. Eksperimentalno dobivene vrijednosti za pojedine uzorke

\begin{tabular}{|c|c|c|c|c|c|c|c|c|c|c|}
\hline $\begin{array}{c}\text { Specimen No. } \\
\text { Uzorak br. }\end{array}$ & $\boldsymbol{m}$ & $\boldsymbol{\rho}$ & $\boldsymbol{F}_{\max }$ & $\mathbf{w}^{*}$ & $\mathbf{w}$ & $\boldsymbol{E}_{\mathbf{b}}$ & $\boldsymbol{R}_{\mathbf{b}}$ & $\boldsymbol{w}_{\mathbf{1}}$ & $\boldsymbol{w}_{\mathbf{2}}$ & $\boldsymbol{R}^{\mathbf{2}}$ \\
\hline & $\mathrm{g}$ & $\mathrm{kg} / \mathrm{m}^{3}$ & $\mathrm{kN}$ & $\mathrm{mm}$ & $\mathrm{mm}$ & $\mathrm{MPa}$ & $\mathrm{MPa}$ & $\mathrm{mm}$ & $\mathrm{mm}$ & \\
\hline 1 & 152.3 & 513.0 & 2.643 & 34.6188 & 17.3094 & 10624.0 & 74.5 & 1.14592 & 4.83916 & 0.9999 \\
\hline 2 & 150.8 & 508.0 & 2.458 & 31.4688 & 15.7344 & 11070.0 & 69.2 & 1.13983 & 4.68429 & 0.9998 \\
\hline 3 & 165.8 & 558.5 & 2.979 & 28.7375 & 14.3688 & 15738.0 & 83.9 & 0.83749 & 3.33063 & 1.0000 \\
\hline 4 & 169.6 & 571.3 & 2.579 & 27.1000 & 13.5500 & 14414.0 & 72.6 & 0.86025 & 3.5824 & 0.9995 \\
\hline 5 & 155.5 & 523.8 & 2.777 & 37.8688 & 18.9344 & 13157.6 & 78.2 & 0.91057 & 3.89265 & 1.0000 \\
\hline 6 & 162.5 & 547.4 & 3.062 & 32.3875 & 16.1938 & 14510.4 & 86.3 & 0.89047 & 3.59453 & 0.9995 \\
\hline 7 & 150.5 & 506.9 & 2.171 & 22.5063 & 11.2531 & 11518.3 & 61.2 & 1.03163 & 4.43813 & 0.9991 \\
\hline 8 & 153.9 & 518.4 & 2.936 & 30.4813 & 15.2406 & 14785.6 & 82.7 & 0.78059 & 3.43433 & 1.0000 \\
\hline 9 & 165.1 & 556.1 & 2.639 & 31.0688 & 15.5344 & 11710.7 & 74.3 & 1.06821 & 4.41875 & 0.9994 \\
\hline 10 & 159.7 & 537.9 & 2.684 & 30.1625 & 15.0813 & 11825.1 & 75.6 & 1.03245 & 4.35058 & 1.0000 \\
\hline $\begin{array}{c}\text { Average } \\
\text { Prosječno }\end{array}$ & 158.6 & 534.1 & 2.693 & 30.6400 & 15.3200 & 12935.4 & 75.9 & & & \\
\hline
\end{tabular}




\subsection{Evaluation of modulus of elasticity in bending} 2.3. Određivanje modula elastičnosti pri savijanju

Modulus of elasticity in bending $E_{b}(\mathrm{MPa})$ (Table 2) was determined with the use of relation (3) according to ČSN EN 408, where $l$ - free sample length, $\mathrm{m}, b$ - width of cross-section, $\mathrm{m}$ and $h$ - height of crosssection, $\mathrm{m}$, and $a$-distance of load from support $(6 \cdot h)$, $\mathrm{m}$ (Fig. 1). The difference $\left(F_{2}-F_{1}\right)$ and $\left(w_{2}-w_{1}\right)$ shows the growth of loading and vertical displacement on the linear part of the load - displacement diagram. The values $F_{1}, F_{2}, w_{1}$ and $w_{2}$ were determined with the use of load-displacement diagram in Fig. $2 ; F_{1}=0.269 \mathrm{kN}$ and $F_{2}=1.077 \mathrm{kN}$. The measured values are arranged in Table 2, where $m$ - weight, $\mathrm{g}, F_{\max }-$ limit load, $\mathrm{kN}$, $w^{*}-$ measured vertical displacement, mm, $w$ - converted vertical displacement at midspan, $\mathrm{mm}$ and $R^{2}-$ value of reliability.

$$
E_{b}=\frac{l^{3} \cdot\left(F_{2}-F_{1}\right)}{b \cdot h^{3} \cdot\left(w_{2}-w_{1}\right)} \cdot\left[\left(\frac{3 \cdot a}{4 \cdot l}\right)-\left(\frac{a}{l}\right)^{3}\right]
$$

\subsection{Evaluation of bending strength}

2.4. Određivanje čvrstoće na savijanje

Bending strength $R_{\mathrm{b}}(\mathrm{MPa})$ (Table 2) was determined with the use of the relation (4) according to C $\mathrm{SN}$ EN 408, where $b$ - width of cross-section, $\mathrm{m}$, and $h-$ height of cross-section, m, $a$ - distance of load from support $(6 \cdot h)$, m and $F_{\text {max }}$ - limit load of specimen.

$$
R_{b}=\frac{3 \cdot F_{\max } \cdot a}{b \cdot h^{2}}
$$

\subsection{Numerical analysis of experimental testing} 2.5. Numerička analiza eksperimentalnog ispitivanja

When modelling wood by the finite element method (Bathe, 2006; Tankut et al., 2014), several approaches to wood modelling can be used. The approaches are based on simplifications of the real natural material. The modelling idealizes the real trunk of generally cone shape as a cylindrical object (Bodig and Jayne, 1993), idealizes annual rings as constant shape, thickness and curvature, local failures (knots, cracks),

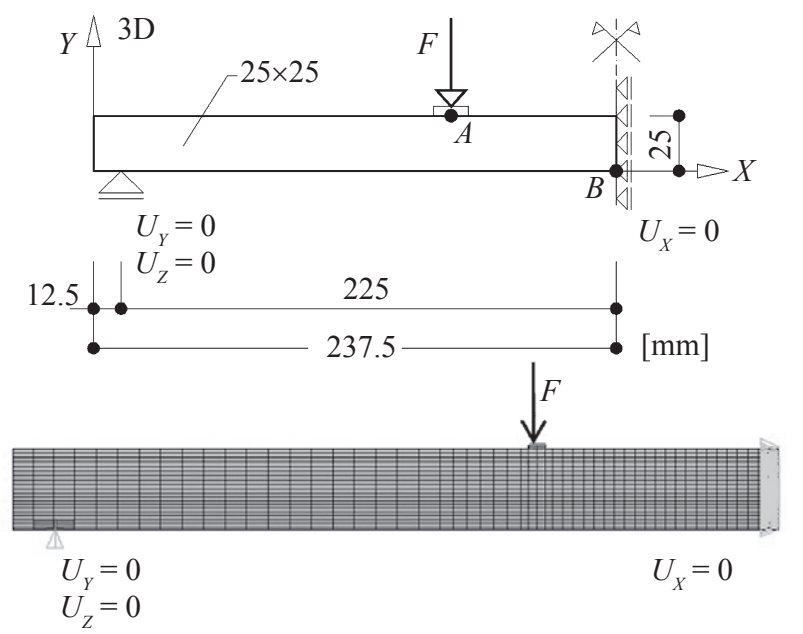

Figure 3 Geometry and 3D numeric model of wooden specimens in the calculation system ANSYS

Slika 3. Geometrijski i numerički 3D model drvnih uzoraka u računalnom sustavu ANSYS

variable structure of material, and differences between earlywood and latewood.

The numerical modelling of experimental testing of specimens idealized annual rings of individual specimens as cylindrical surfaces (Fig. 4) and the behaviour of wood was described with the use of anisotropic plasticity material model (Moses and Prion, 2004). The model was described with elastic and material constants shown in Table 1. The material constants were adjusted in order to meet the conditions of plasticity incompressibility and closed surface plasticity of elliptical shape mentioned by Moses and Prion (2004) and ANSYS (2012a). The material model was complemented with non-interactive failure criterion - maximum stress criterion (Vinson and Sierakowski, 2002), in order to allow the description of wood failure by brittle failure in tension. Neither the hardening of material, nor the limitation concerning the plasticity reserve was considered for compression.

Ten 3D numerical models of specimens were made in the calculation system ANSYS version 14.0 (ANSYS, 2012a). The models were created with the
1

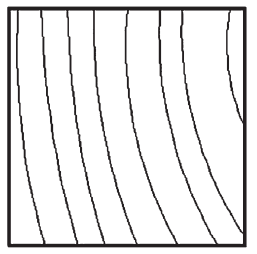

6

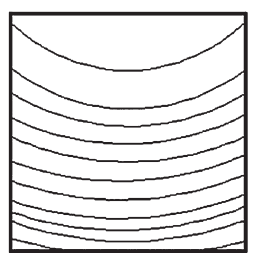

2

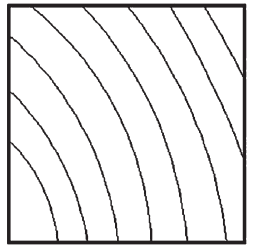

7

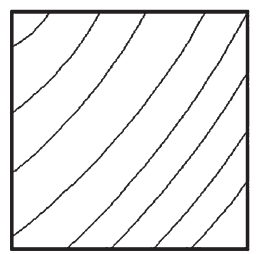

3

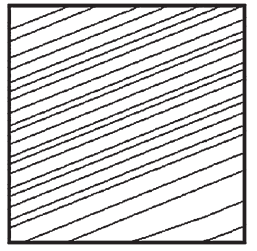

8

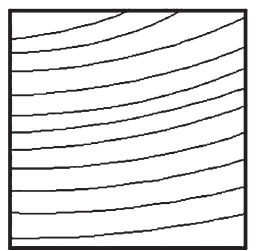

4

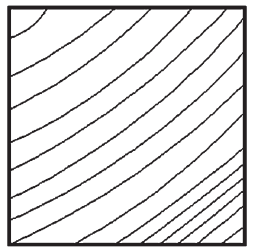

9

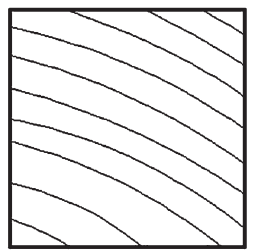

5

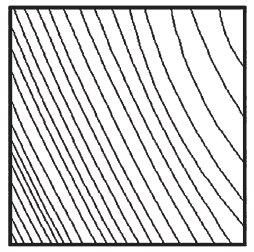

10

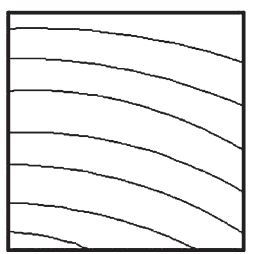

Figure 4 Idealised annual ring characteristics found from the characteristics of annual rings at the specimen front Slika 4. Idealizirani godovi na poprečnom presjeku uzoraka 
use of solid finite elements of SOLID45 and SURF154 type (ANSYS, 2012a).

In order to reduce the time demanding nature of calculations, symmetric boundary conditions were considered (Cook et al., 2001), i.e. specimen halves were modelled of a size of $25 \times 25 \times 237.5 \mathrm{~mm}$ (Fig. 3 ). In the transversal direction, the line load (line $A$ ) was distributed on specimens with the use of a distribution board (Fig. 3)

The cross sections of numerical models considered the characteristics of annual rings. The modelling of the characteristics of annual rings was based on one of two front views of specimens. General cone shape of the trunk, as well as the spiral arrangement of grains along the whole length of the trunk, was neglected. The characteristics of annual rings in the front were replaced with cylindrical surfaces, and the specimens were expected to have constant curvature along the length. The cross sections of specimens are shown in Fig. 4.

The calculations were made in steps, taking into account material non-linearity. In addition, the effect of large displacements and rotations of finite elements, i.e. geometric non-linearity, was taken into account.

\section{RESULTS AND DISCUSSION}

3. REZULTATI I RASPRAVA

\subsection{Results of experimental testing}

3.1. Rezultati eksperimentalnog ispitivanja

On average, the failure of tested specimens occurred under the force of $2.693 \mathrm{kN}$ (Table 2). The min- imum force of $2.171 \mathrm{kN}$ at the failure was measured when testing specimen No. 7. In contrast, the maximum force of $3.062 \mathrm{kN}$ at the failure was measured when testing specimen No. 6 . The experimentally measured variation strength coefficient at failure is $9.83 \%$.

The average value of the modulus of elasticity in bending $E_{\mathrm{b}}$, determined by experimental testing of 10 specimens, is $12935.4 \mathrm{MPa}$. The measured values of the modulus of elasticity in bending ranged within the interval of $10624.0 \mathrm{MPa}$ (min; specimen No. 1) to 15738.0 MPa (max; specimen No. 3). The experimentally measured variation coefficient of the modulus of elasticity in bending is $14.0 \%$, which is a lower value than that of $22 \%$ mentioned by Bergman et al. (2010) and Jírů (1970).

The average value of bending strength $R_{b}$ is 75.9 $\mathrm{MPa}$. Minimum and maximum values of bending strength do not correspond to the same samples used for measuring modulus of elasticity in bending. The measured values of bending strength ranged within the interval of 61.2 $\mathrm{MPa}$ (min; specimen No. 7) to 86.3 MPa (max; specimen No. 6). The experimentally measured variation coefficient of bending strength is $9.8 \%$, which is again a lower value than that of $16 \%$ mentioned by Bergman et al. (2010) and Jírů (1970).

The value of modulus of elasticity in bending $E_{b}$ and bending strength $R_{\mathrm{b}}$ depends on the orientation and density of annual rings (Table 2 and Fig. 4). Higher values $E_{\mathrm{b}}$ and $R_{\mathrm{b}}$ were shown by samples with higher density of annual rings and specimens, whose annual rings were convex when looking at the specimen front.
1

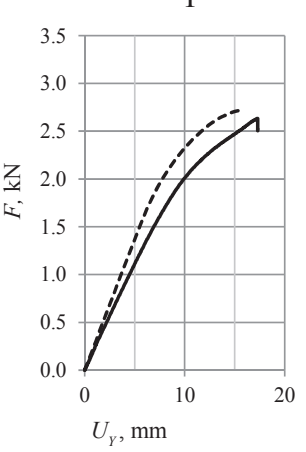

6

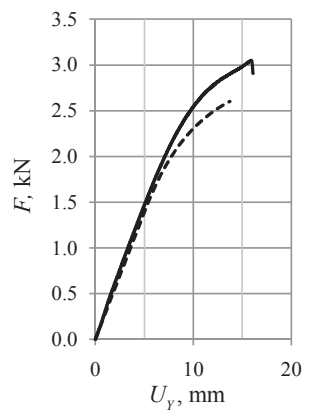

2

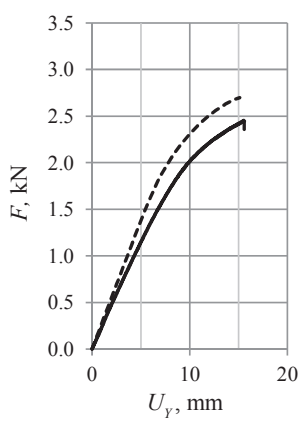

7

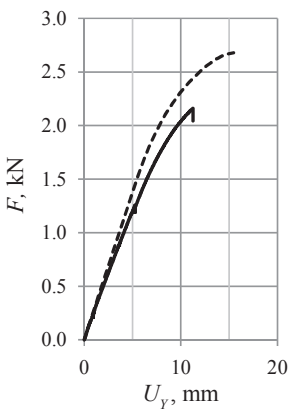

----- Numerical analysis

3

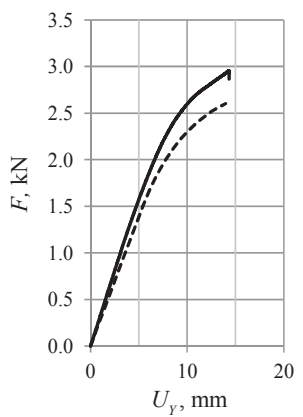

8

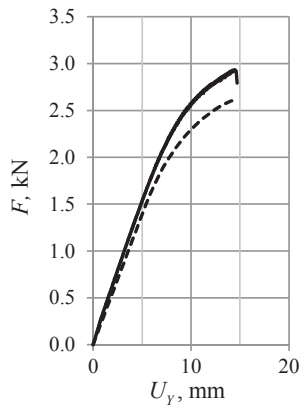

4

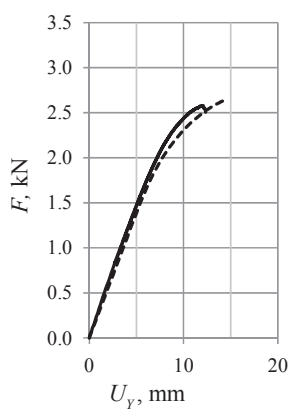

9

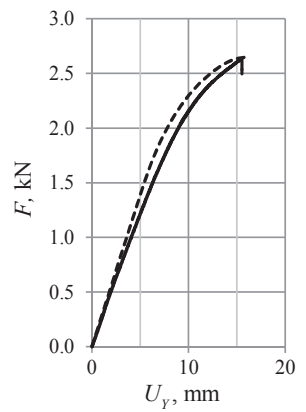

Experimental testing

Figure 5 Load displacement diagrams $\left(F-U_{Y}\right)$ of specimens determined by numerical analysis and experimental testing Slika 5. Dijagram opterećenje - pomak za ispitivane uzorke određen numeričkom analizom eksperimentalnog ispitivanja 
Table 3 Results of experimental measurement of strength at the failure limit $F(\mathrm{kN})$ and vertical displacement $U_{\mathrm{Y}}$ at point B at midspan with numerically determined values

Tablica 3. Rezultati eksperimentalnog mjerenja čvrstoće pri maksimalnom opterećenju $F(\mathrm{kN})$ i vertikalnom pomaku $U_{\mathrm{Y}} \mathrm{u}$ točki B u sredini raspona s numerički utvrđenim vrijednostima

\begin{tabular}{|c|c|c|c|c|c|c|}
\hline $\begin{array}{c}\text { Specimen No. } \\
\text { Uzorak } b r .\end{array}$ & $\boldsymbol{w}$ & $\boldsymbol{F}_{\max }$ & $\boldsymbol{U}_{\mathbf{Y}}$ & $\boldsymbol{F}_{\max , \mathbf{N A}}$ & $\boldsymbol{w} / \boldsymbol{U}_{\mathbf{Y}}$ & $\boldsymbol{F}_{\max } / \boldsymbol{F}_{\max , \mathbf{N A}}$ \\
\cline { 2 - 7 } & $\mathrm{mm}$ & $\mathrm{kN}$ & $\mathrm{mm}$ & $\mathrm{kN}$ & $\%$ & $\%$ \\
\hline & \multicolumn{2}{|c|}{$\begin{array}{c}\text { Experimental testing } \\
\text { Eksperimentalni podaci }\end{array}$} & \multicolumn{2}{|c|}{$\begin{array}{c}\text { Numerical analysis } \\
\text { Numerička analiza }\end{array}$} & & \\
\hline 1 & 17.3094 & 2.643 & 15.9896 & 2.723 & -8.25 & 2.91 \\
\hline 2 & 15.7344 & 2.458 & 15.1248 & 2.698 & -4.03 & 8.90 \\
\hline 3 & 14.3688 & 2.979 & 13.9851 & 2.601 & -2.74 & -14.53 \\
\hline 4 & 13.5500 & 2.579 & 14.2121 & 2.631 & 4.66 & 1.98 \\
\hline 5 & 18.9344 & 2.777 & 15.4661 & 2.696 & -22.42 & -2.99 \\
\hline 6 & 16.1938 & 3.062 & 13.7368 & 2.601 & -17.89 & -17.74 \\
\hline 7 & 11.2531 & 2.171 & 15.4568 & 2.678 & 27.20 & 18.96 \\
\hline 8 & 15.2406 & 2.936 & 14.5737 & 2.610 & -4.58 & -12.51 \\
\hline 9 & 15.5344 & 2.639 & 15.9157 & 2.647 & 2.40 & 0.32 \\
\hline 10 & 15.0813 & 2.684 & 14.8208 & 2.618 & -1.76 & -2.52 \\
\hline Average & 15.3200 & 2.693 & 14.9282 & 2.650 & - & - \\
\hline
\end{tabular}

\subsection{Results of numerical analysis of experimental} testing

3.2. Rezultati numeričke analize eksperimentalnog ispitivanja

The load curves $F-U_{Y}$ at point B (Fig. 3) are shown in Fig. 5. Very good conformity between experimental tests and numerical analysis was reached with the specimen No. 4, 5, 6, 9 and 10. Regarding the specimen No. 1, 2 and 7, the hardness values of the numerical and material model, respectively, were higher than those of wood specimens. Load curves of specimen No. 3 and 8 are located under the experimentally determined load curves, indicating lower rigidity of the numerical and material model, respectively.

The average strength at the failure limit determined by experimental testing $(2.693 \mathrm{kN})$ differs from the average strength at the failure limit determined by numerical modelling $(2.650 \mathrm{kN})$ by $-1.62 \%$ (Table 3 ). The difference of the average measured vertical displacement at midspan $(15.32 \mathrm{~mm})$ and numerically determined values $(14.93 \mathrm{~mm})$ is $-2.61 \%$.

\section{CONCLUSIONS}

\section{ZAKLJUČAK}

The determined value of average modulus of elasticity in bending $E_{\mathrm{b}} 12935.4 \mathrm{MPa}$ by experimental testing differs from the values stated in literature for Scots pine (Pinus sylvestris) $12800 \mathrm{MPa}$ (Table 1) by $1.05 \%$. The average bending strength $R_{\mathrm{b}} 75.9 \mathrm{MPa}$ determined with the use of the same group of specimens differs by $11.74 \%$ from the published value of 86.0 MPa. The determined average values $E_{\mathrm{b}}$ and $R_{\mathrm{b}}$ confirm the values of these constants mentioned in the paper of Matovič (1993) and Požgaj et al. (1997, 2004). The partial results of experimental testing of specimens show that constants $E_{\mathrm{b}}$ and $R_{\mathrm{b}}$ are dependent on the orientation and density of annual rings.

The use of anisotropic plasticity material model (Moses and Prion, 2004) for wood modelling with elastic and material constants according to Table 1, while taking into account non-interactive failure criterion and the idealisation of the annual rings characteristics, showed good agreement between the results of numerical analysis and experimental testing of wood specimens. The difference between experimentally and numerically determined results is on average up to $2.7 \%$. Numerically determined load curves follow the load curves determined by experimental testing. The use of anisotropic plasticity material model can be seen on examples of load test modelling, numerical determination of load bearing capacity, i.e. in cases when the level of the applied loading is higher than the load when the material failure occurs. Otherwise, the above described approach can be replaced by a simpler, orthotropic material model with elastic constants according to Table 1 and interactive failure criteria - Hoffman (Hoffman, 1967) and Tsai-Wu criterion (Tsai and Wu, 1971).

\section{Acknowledgments - Zahvala}

This paper has been worked out under the project No. LO1408 "AdMaS UP - Advanced Materials, Structures and Technologies", supported by Ministry of Education, Youth and Sports under the „National Sustainability Programme I" and under the project FAST-S-15-2757 supported by the IGA, Brno University of Technology, Czech Republic.

\section{REFERENCES}

\section{LITERATURA}

1. Bathe, K. J., 2006: Finite element procedures. [New ed.] [S.l: s.n.].

2. Bergman, R.; Cai, Z.; Carll, Ch. G.; Clausen, C. A.; Dietenberger, M. A.; Falk, R. H.; Frihart, Ch. R.; Glass, S. V.; Hunt, Ch. G.; Ibach, R. E.; Kretschmann, D. E.; Rammer, R. J.; Ross, R. J.; Stark, N. M., 2010: Wood Handbook, Wood as an Engineering Material (All Chapters). Forest Products Laboratory. Wood handbook - Wood as an engineering material. General Technical Report FPLGTR-190. Madison, WI: U.S. Department of Agriculture, Forest Service, Forest Products Laboratory.

3. Bodig, J.; Goodman, J. R., 1973: Prediction of Elastic Parameters for Wood. Wood Science, 5(4): 249-264. 
4. Bodig, J.; Jayne, B. A., 1993: Mechanics of wood and wood composities. Reprint ed. Malabar, Fla.: Krieger Pub., 1993, xxi, 712 p.

5. Danielsson, H.; Gustafsson, P. J., 2013: A three dimensional plasticity model for perpendicular to grain cohesive fracture in wood. Engineerimg Fracture Mechanics, (98): 137-152.

http://dx.doi.org/10.1016/j.engfracmech.2012.12.008

6. Gillis, P. P., 1972: Orthotropic elastic constants of wood. Wood Science and Technology, 6(2): 138-156. http://dx.doi.org/10.1007/BF00350827

7. Hallai, J., 2008: Fracture of Orthotropic Materials under Mixed Mode Loading: EM 388F Fracture Mechanics: Term Paper. Austin, Texas: University of Texas at Austin, Department of Aerospace Engineering and Engineering Mechanics, (online).

http://imechanica.org/files/Julian's\%20Term\%20Paper.pdf (Accessed September 28, 2013).

8. Hoffman, O., 1967: The Brittle Strength of Orthotropic Materials. Journal of Composite Materials, 1: 200-206. http://dx.doi.org/10.1177/002199836700100210

9. Morais, J. L.; Xavier, J. C.; Dourado, N. M.; Lousada, J. L., 2001: Mechanical behaviour of wood in the orthotropic directions. In: SharePDF.net - Free Download PDF File (online).

http://sharepdf.net/view/87548/mechanical-behaviourof-wood-in-the-orthotropic-directions

(Accessed September 24, 2013).

10. Hearmon, R. F. S., 1948: The Elasticity of Wood and Plywood. Forest Products Research Special Report, 7(1):187.

11. Jeong, G. Y.; Hindman, D. P.; Zink-Sharp, A., 2010: Orthotropic properties of loblolly pine (Pinus taeda) strands. Journal of Materials Science, 45 (21): 5820-5830. http://dx.doi.org/10.1007/s10853-010-4658-2

12. Jírů, P., 1970: Dřevařská technická příručka - Oddíl první - Dřevo. SNTL - Nakladatelství technické literatury.

13. Kim, Y. J.; Harries, K. A., 2010: Modeling of timber beams strengthened with various CFRP composites. Engineering Structures, (32): 3225-3234.

http://dx.doi.org/10.1016/j.engstruct.2010.06.011

14. Kuklík, P.; Vídeňský, J., 2005: Stanovení komplexu fyzikálně-mechanických a fyzikálně-chemických charakteristik. In: Centre for Integrated DEsign of Advanced Structures: Uplatněni pokročilých materiálù $v$ integrovaném návrhu konstrukci. Prague: CIDEAS, pp. 1-2.

15. Martin, P. A.; Berger, J. R., 2001: Waves in wood: free vibrations of a wooden pole. Journal of the Mechanics and Physics of Solids, (49): 1155-1178. http://dx.doi.org/10.1016/S0022-5096(00)00068-5

16. Matovič, A., 1993: Fyzikální a mechanické vlastnosti dřeva a materiálů na bázi dřeva, Brno: Vysoká škola zemědělská.

17. Morais, J. L., Xavier, J. C., Dourado, N. M., Lousada, J. L., 2001: Mechanical behaviour of wood in the orthotropic directions. In: SharePDF.net - Free Download PDF File (online).

http://sharepdf.net/view/87548/mechanical-behaviourof-wood-in-the-orthotropic-directions

(Accessed September 24, 2013)

18. Moses, D. M.; Prion, H. G. L., 2004: Stress and failure analysis of wood composites: a new model. Composites: Part B: engineering, (35): 251-261. http://dx.doi.org/10.1016/j.compositesb.2003.10.002

19. Nairn, J. A., 2007: Numerical Modeling of Deformation and Fracture of Wood including Heterogeneity and Anisotropy. COST Action E35 Meeting, Lausanne, Switzerland, 2007 (online).
20. Dostupné: http://www.cof.orst.edu/cof/wse/faculty/Nairn/ papers/NairnCOST.pdf (Accessed September 24, 2013).

21. Pěnčík, J., 2013: Dřevěné segmentové schodiště s jednostranně zavěšenými stupni. Brno, 2013. Habilitation thesis.

22. Pousette, A., 2006: Testing and modeling of the behavior of wooden stairs and stair joints. Journal of Wood Science, 52(4): 358-362. http://dx.doi.org/10.1007/s10086-005-0778-8

23. Požgaj, A.; Chovanec, D.; Kurjatko, S.; Babiak, M., 1997: Štruktura a vlastnosti dreva, Priroda, Bratislava.

24. Tankut, N.; Tankut, A. N.; Zor, M., 2014: Finite Element Analysis of Wood Materials. Drvna industrija, 65(2): 159-171. http://dx.doi.org/10.5552/drind.2014.1254

25. Tsai, S. W., Wu, E. M., 1971: A General Theory of Strength for Anisotropic Materials. Journal of Composite Materials, (5): 58-79. http://dx.doi.org/10.1177/002199837100500106

26. Úřadníček, L., Maděra, P., Tichá, S., Koblížek, J., 2001: Dřeviny České republiky. 2. ed. Písek: Matice lesnická.

27. Vinson, J. R., Sierakowski, R., 2002: The behavior of structures composed of composite materials. 2nd ed. Boston: Kluwer Academic Publishers, xiv, 435 p. http://dx.doi.org/10.1007/0-306-48414-5

28. Winandy, J. E., 1994: in Encyclopedia of agricultural science, ed. Arntzen, Ch. J., Ritter, E. M. Academic Press, New York, 4: 549-561.

29. Xavier, J., 2007: Identification de la variabilité des rigidités du bois á l'intérieur de l'arbre par la méthode des champs virtuels: application au P. Pinaster dans le plan LR. Paris. Thése pour obtenir la grade de Docteur. E. N.S.A.M (Ecole Nationale Supérieure des Arts et Métiers). (online). (Accessed September 28, 2013).

30. ***2004: "Fyzikální a mechanické vlastnosti dřeva" (online), Mendel University in Brno, wood.mendelu.cz/cz/ sections/Props/?q=node/56. First published 2004 (Accessed Sept. 20, 2013).

31. ***2006: "Spider8 from HBM" (online), HBM Inc., http://www.hbm.com/fileadmin/mediapool/hbmdoc/ technical/b0409.pdf. First published 2006 (Accessed Sept. 20, 2013).

32. *** ANSYS ${ }^{\circ}$ Academic Research, Release 14.5, ANSYS, Inc., 2012a.

33. ***2012: "HBM WA T - Inductive displacement transducer (Probe)" (online), HBM Inc.

http://www.hbm.com/en/menu/products/transducerssensors/displacement/wa-t/\#c71014 (Accessed Sept. 20, 2013).

34. ***2012a: “EUFORGEN: Distribution maps" (online), EUFORGEN.

http://www.euforgen.org/distribution_maps.html (Accessed Sept. 20, 2013).

35. *** ČSN EN 408 (73 1741), 2004: Timber structures Structural timber and glued laminated timber - Determination of some physical and mechanical properties.

\section{Corresponding address:}

Assist. Prof. Ing. JAN PĚNČÍK, Ph. D.

Institute of Building Structures

Faculty of Civil Engineering

Brno University of Technology

CZECH REPUBLIC

e-mail: pencik.j@fce.vutbr.cz 